\title{
Immunomodulatory properties of human adult and fetal multipotent mesenchymal stem cells
}

\author{
Pei-Min Chen ${ }^{1}$, Men-Luh Yen ${ }^{2}$, Ko-Jiunn Liư ${ }^{3}$, Huey-Kang Sytwu ${ }^{4}$ and B-Linju Yen ${ }^{1,5^{*}}$
}

\begin{abstract}
In recent years, a large number of studies have contributed to our understanding of the immunomodulatory mechanisms used by multipotent mesenchymal stem cells (MSCs). Initially isolated from the bone marrow (BM), MSCs have been found in many tissues but the strong immunomodulatory properties are best studied in BM MSCs. The immunomodulatory effects of BM MSCs are wide, extending to T lymphocytes and dendritic cells, and are therapeutically useful for treatment of immune-related diseases including graft-versus-host disease as well as possibly autoimmune diseases. However, BM MSCs are very rare cells and require an invasive procedure for procurement. Recently, MSCs have also been found in fetal-stage embryo-proper and extra-embryonic tissues, and these human fetal MSCS (F-MSCS) have a higher proliferative profile, and are capable of multilineage differentiation as well as exert strong immunomodulatory effects. As such, these F-MSCs can be viewed as alternative sources of MSCs. We review here the current understanding of the mechanisms behind the immunomodulatory properties of BM MSCs and F-MSCs. An increase in our understanding of MSC suppressor mechanisms will offer insights for prevalent clinical use of these versatile adult stem cells in the near future.
\end{abstract}

Keywords: mesenchymal stem cells, bone marrow, fetal, multilineage differentiation, immunomodulation, T lymphocytes, natural killer lymphocytes, dendritic cells, major histocompatibility complex (MHC) molecules

\section{Mesenchymal stem cells: Definition and functional capacity}

Human mesenchymal stem cells (MSCs) are a population of multilineage progenitor cells with the ability to differentiate into multiple mesenchymal lineages such as chondrocytes, osteoblasts, or adipocytes [1,2]. The initial isolation of MSCs was from the bone marrow (BM) based on plastic adherence of the cells as opposed BM hematopoieitic cells which can be cultured in suspension [3]. Increasingly, MSCs have been reported to be isolated from a number of other organs in the adult [4-7] and fetal-stage tissue [8-13]. Due to the difficulty in comparing the various methods used to isolate BM and tissue MSCs, a recent movement to define these progenitor cells have proposed a minimal criteria for MSCs in terms of trilineage mesodermal differentiation capacity and expression of a specific panel of cell surface marker including being positive for CD73, CD90, and

\footnotetext{
* Correspondence: blyen@nhri.org.tw

'Regenerative Medicine Research Group, Institute of Cellular and System Medicine, National Health Research Institutes (NHRI), Zhunan, Taiwan Full list of author information is available at the end of the article
}

CD105; and negative for hematopoietic markers such as CD14 or CD11b, CD34, CD45, and CD19 or CD79a [14]. The ease of isolation of MSCs along with reports of differentiation into extra-mesodermal cell types has made MSCs a popular choice for cell therapy for preclinical and clinical trials of a variety of diseases $[15,16]$.

\section{Immunomodulatory Properties of Adult and Fetal-stage MSCs}

One important reason for the abundant number of clinical studies using adult BMMSCs is the immunomodulatory properties of these cells [17-20]. As with organ transplantation, a critical issue in stem cell therapy is the rejection resulting from immune incompatibility between donor and recipient. BMMSCs' immunomodulatory properties appear to obviate this major obstacle for cell therapy [21]; moreover, these immunosuppressive effects allow for an even wider range of disease indications for these progenitor cells, including use for immune-related diseases [4,22-26]. BMMSCs appear to be poorly immunogenic [27], since they constitutively express low levels of major histocompatibility complex (MHC) class I
Ciomed Central

() 2011 Chen et al; licensee BioMed Central Ltd. This is an Open Access article distributed under the terms of the Creative Commons Attribution License (http://creativecommons.org/licenses/by/2.0), which permits unrestricted use, distribution, and reproduction in any medium, provided the original work is properly cited. 
molecules and no MHC class II molecules. Moreover, BMMSCs do not express co-stimulatory molecules such as CD40, CD80, or CD86 which are involved in the activation of $\mathrm{T}$ cell for transplant rejection $[18,28,29]$. Several studies show that differentiated and undifferentiated BMMSCs have suppressive effects on alloantigen- and mitogen-stimulated lymphocyte proliferation in in vitro studies using mixed lymphocyte reactions (MLR), with a concomitant reduction in the production of proinflammatory cytokines such as interferon- $\gamma($ IFN- $\gamma$ ) and tumor necrosis factor- $\alpha$ (TNF- $\alpha)[17,18,30]$. Thus, the clinical indications for human BMMSCs are considerably wider than other human stem cells, ranging from cell replacement for degenerative diseases-common indications for stem cell therapy-as well as immune-related diseases including autoimmune diseases and transplantation rejection [4,22-26].

While the differentiation plasticity and immunomodulatory properties of adult BMMSCs have brought much excitement in terms of prevalent clinical use for these progenitor cells, the fact remains that these cells are very rare, with cell numbers and proliferative capacity further decreasing with age $[31,32]$. In addition, an invasive procedure in terms of BM aspiration is needed to obtain BMMSCs. Thus, investigators have worked to identify other abundant and easily attainable sources of MSCs for therapeutic use. While many other adult tissues appear to harbor MSCs as well [4], the problems of requiring invasive procedures to obtain these relatively rare cells remain. A number of labs have thus turned to using discarded post-partum fetal-stage tissue for isolation of progenitor cells, since fetal umbilical cord blood is known to be a good source for the hematopoietic stem cell, one type of highly used stem cells. Known to be important in mediating the fetomaternal tolerance of pregnancy, fetalstage extra-embryonic tissues are easily accessible sources for isolation of cells since these tissues are discarded at birth, obviating ethical issues as well.

Fetal MSCs (F-MSCs) have been derived from a number of fetal tissues, including fetal liver and bone marrow [13]. Moreover, extra-embryonic structures of fetal origin are also good sources for MSCs since they are discarded after birth, and MSCs isolated from human umbilical cord blood (UCB)(hUCB-MSCs) $[9,33]$, the Wharton's Jelly (hWJ-MSCs) of the umbilical cord itself [34], amniotic fluid (AF)(hAF-MSCs)[10,35], amnion (hA-MSCs) [36], and the placenta (hP-MSCs) [8,37-39] have been demonstrated. These increasing reports on the isolation of MSCs from all these fetal-stage tissues demonstrate that F-MSCs can be an abundant and viable source of MSCs.

In addition to multilineage differentiation capacity, F-MSCs have been demonstrated to harbor strong immunomodulatory effects as well. F-MSCs lack or exhibit very low expression of highly polymorphic $\mathrm{MHC}$ class I (HLA-A, HLA-B, and HLA-C); furthermore, they do not express surface MHC class II molecules (HLADP, HLA-DQ, and HLA-DR) nor co-stimulatory molecules, such as CD40, CD40 ligand, CD80, and CD86 [10,34,35,40-52]. F-MSCs not only fail to induce an allogeneic or xenogeneic immune response in MLR, but also strongly suppress lymphocyte proliferation induced by mitogens or alloantigens, often in a dose-dependent manner [53-57]. Based on these data, F-MSCs appear to be as least as non-immunogenic as BMMSCs, and in some reports, appear to be even more immunomodulatory than its adult counterpart [40]. This is supported by clinical experience in hematopoietic stem cell transplantation (HSCT), where lower incidences of immunerelated consequences are consistently seen after UCB HSCT compared to BM HSCT [21].

Based on the accumulating data, it appears that both adult-source MSCs-most prominently BMMSCS-and F-MSCs are good candidates for cell therapy for immune-related diseases in addition to degenerative diseases. In general, the overwhelming majority of the data is based on studies with BMMSCs rather than F-MSCs, since F-MSCs are newer sources of MSCs and have been studied only in the past few years. This review focuses on evidence for the immunomodulation of adult BMMSCs and F-MSCs, properties which appear increasingly relevant for clinical use. Interactions of BMMSCs and F-MSCs with subpopulations of leukocytes, and mechanisms of actions-when investigated-are reviewed.

\section{Interactions of human BMMSCs and F-MSCs with leukocyte subpopulations}

\subsection{Interactions with T Lymphocytes}

Currently, the interactions of MSCs with T lymphocytes are the best studied. Many reports have shown that BMMSCs affect several properties of T cells, most prominently efficiently suppressing activated $C D 4^{+} \mathrm{T}$ helper cell and $\mathrm{CD}^{+}$cytotoxic $\mathrm{T}$ cell (CTL) proliferation $[19,29,58-60]$. Activated T cells are arrested by BMMSCs in the G0/G1 phase of the cell cycle [61], but apoptosis is not induced $[19,29]$. Besides their ability to impair the proliferation of activated T cells, BMMSCs can prolong the survival of unstimulated $\mathrm{T}$ cells by rescuing the lymphocytes from activation-induced cell death by downregulation of Fas receptor and Fas ligand on $\mathrm{T}$ cells and inhibition of endogenous proteases involved in cell death [62]. Further studies have shown that BMMSCs reduce IFN- $\gamma$ production by $C D 4^{+}$Th 1 cells and interleukin (IL)-17 release by CD4 ${ }^{+}$Th17 lymphocytes, whereas IL-4 secretion by $\mathrm{CD} 4^{+}$Th2 cells is augmented [58,63-66]. The cytolytic potential of CTLs can also be efficiently impaired by BMMSCs [67]. Recently, several studies investigated the impact of BMMSCs on $\mathrm{T}$ regulatory 
lymphocytes (Tregs), a population of $\mathrm{CD} 4^{+} \mathrm{CD} 25^{\text {high }}$ cells which play an important role in the induction of peripheral tolerance and the inhibition of proinflammatory immune responses [68-70]. Many studies have shown that BMMSCs cultured with stimulated peripheral blood mononuclear cells (PBMCs) can induce the expansion of functional $\mathrm{CD} 4^{+} \mathrm{CD} 25^{\text {high }}$ Foxp $3^{+}$Tregs $[58,66,67,71-75]$. A number of mechanisms have been suggested-both cell-contact dependent and independent mechanisms-but there is no clear consensus as of yet; for example, transforming growth factor- $\beta$ (TGF- $\beta$ ) has been cited as being involved in one study [71] but not in another study [72]. This discrepancy may be due to the subtle phenotypic variations induced in BMMSCs by the many methods available for isolation of these adult stem cells.

Several studies have attempted to delineate which specific molecules are involved in the immunomodulatory effect of BMMSCs on T-cell proliferation and effector functions. In the human system, the effects of BMMSCs on $\mathrm{T}$ cells are mainly mediated through cell-contact independent processes, implicating the importance of secreted factors [76]. These molecules include IL-1 $\beta$ [77], TGF- $\beta 1[19,71,77]$, hepatocyte growth factor (HGF)[19], prostaglandin $\mathrm{E}_{2}\left(\mathrm{PGE}_{2}\right)[58,71,78,79]$, indoleamine 2,3-dioxygenase (IDO)[59,79-81], heme oxygenase-1 (HO-1) [82], leukemia inhibitory factor (LIF)[83], insulin-like growth factor (IGF)[84], soluble human leukocyte antigen G5 (sHLA-G5)[74,85], galectin [86,87], and Jagged-1 [88]. Most of the inhibitory soluble factors are not constitutively secreted, but can be induced by the interaction between activated effector cells and BMMSCs (Table 1).

F-MSCs also have been reported to have strong inhibitory effects on T lymphocytes. hWJ-MSCs display potent immunosuppressive properties on $\mathrm{T}$ cell activation in an antigen-independent manner [51], and can also suppress the proliferation of mitogen-stimulated rat splenocytes (xenograft model) or human PBMCs (allogeneic transplant model) in allogeneic MLR in vitro [51]. Furthermore, CD $14^{+}$monocytes promote the immunosuppressive effect of hWJ-MSCs probably via the IL-1 $\beta-\mathrm{PGE}_{2}$ axis. The inflammatory cytokine IL-1 $\beta$ produced by hPBMCs upon activation upregulates the expression of cyclooxygenase-2 (COX-2) and the production of $\mathrm{PGE}_{2}$ by hWJ-MSCs [89-92]. hP-MSCs can also suppress the proliferation of allogeneic $\mathrm{T}$ cells $[40,53,93]$. These effects of hP-MSCs may involve the secretion of soluble factors TGF- $\beta$ and IL-10 $[40,94]$. Both hP-MSCs and hUCB-MSCs have been shown to increase the proportion of Tregs, which contributes to the suppression of $\mathrm{T}$ cell proliferation [40,42] (Figure 1).

Interestingly, a number of reports have demonstrated that in in vitro systems, pretreatment of BMMSCs and
F-MSCs with the pro-inflammatory cytokine IFN- $\gamma$ actually enhances their immunomodulation rather than decreases it $[40,59,95]$. Some investigators have postulated that this may explain the in vivo ability of MSCs to be effective against very inflammatory diseases such as graft-versus-host-disease (GVHD), in which the production of such activating cytokines as IFN- $\gamma$ by $\mathrm{T}$ and natural killer lymphocytes (NKs) may actually promote MSC immunomodulation, subsequently suppressing the proliferation of $\mathrm{CD}^{+}, \mathrm{CD}^{+} \mathrm{T}$ cells, and NKs themselves [59]. While this has not been proven in animal studies, pre-clinical and clinical data continues to reveal therapeutic efficacy after MSC administration, giving indirect evidence for this hypothesis. Interestingly, while IFN- $\gamma$ pre-treatment of adult BMMSCs results in induction of IDO, a strong immunosuppressive enzyme $[59,80]$, MHC II molecules-which can elicit inflammatory responses [96]-are induced as well $[12,40]$, but this does not appear to change the immunomodulatory effects of BMMSCs. It would be critical to elucidate this paradox to better understand why these progenitors possess such strong immunomodulatory properties inherently.

\subsection{Interactions with Dendritic Cells (DCs)}

DCs are derived from monocytes and are potent antigenpresenting cells (APCs) that act by internalizing, shuttling, and presenting antigens to naïve $\mathrm{T}$-cells, which then leads to $\mathrm{T}$-cell activation. These key regulators of immunity display an extraordinary capacity to induce $\mathrm{T}$ cell responses and secrete a variety of cytokines; the differentiation status of DCs can influence whether its target lymphocyte-often T cells-will mount an effector versus a more immunomodulatory response [97]. As such, studies have shown that BMMSCs inhibit the immunostimulatory capacity of DCs, supporting the development of a more tolerogenic population of DCs $[93,98,99]$. BMMSCs markedly impair PBMCs differentiation into DCs and inhibit endocytosis and the production of IL-12 by DCs. In the presence of BMMSCs, the differentiation of $\mathrm{CD} 14^{+}$monocytes into DCs is impaired, and the monocytes retain high expression of CD14 ${ }^{+}-\mathrm{a}$ marker of immaturity for DCs-without the upregulation of CD1a, HLA-DR, or co-stimulatory molecules which prevent the DCs to efficiently induce $\mathrm{T}$ cell effector responses [98]. In addition, BMMSCs also efficiently suppress the $\mathrm{T}$ cell-activating functions of DCs, including stimulation of $\mathrm{T}$-cell proliferation, reduction of naïve $\mathrm{CD}^{+} \mathrm{T}$ lymphocytes polarizing into proinflammatory Th1 cells, and promotion of Th2 responses. BMMSCs can decrease TNF- $\alpha$ secretion by DCs, which then leads to a reduced number of IFN- $\gamma$-producing Th1 cells. APCs generated in the presence of BMMSCs express low levels of IL-12, TNF- $\alpha$, and MHC class II and high levels 
Table 1 Human BMMSC-Derived Immunoregulatory Soluble Factors

\begin{tabular}{|c|c|c|c|}
\hline Leukocyte & Effects & Soluble Factors & References \\
\hline \multirow[t]{14}{*}{ T cells } & Inhibition of T-cell proliferation, cytokine secretion and cytotoxicity & $\mathrm{IL}-1 \beta$ & [77] \\
\hline & & TGF- $\beta 1$ & {$[19,71,77]$} \\
\hline & & $\mathrm{HGF}$ & [19] \\
\hline & & $\mathrm{PGE}_{2}$ & {$[58,71,78,79]$} \\
\hline & & IDO & {$[59,79-81]$} \\
\hline & & $\mathrm{HO}-1$ & [82] \\
\hline & & LIF & [83] \\
\hline & & IGF & [84] \\
\hline & & $\begin{array}{c}\text { HLA-G5/ } \\
\text { other HLA-G }\end{array}$ & {$[74,83]$} \\
\hline & & Galectin-1 & [87] \\
\hline & Apoptosis of activated T-cells & IDO & [81] \\
\hline & Generation of $\mathrm{CD}^{+} \mathrm{CD}^{2} 5^{\text {high }}$ Foxp3 $^{+}$Tregs & HLA-G5 & [74] \\
\hline & & CCL1 (I-309) & [75] \\
\hline & & LIF & [83] \\
\hline DCs & Inhibition of DC maturation & M-CSF & [98] \\
\hline \multirow[t]{4}{*}{ NKs } & Inhibition of NK cell proliferation, cytokine secretion and cytotoxicity & TGF- $\beta$ & [118] \\
\hline & & IDO & {$[59,119]$} \\
\hline & & HLA-G5 & [74] \\
\hline & & $\mathrm{PGE}_{2}$ & {$[59,118,119]$} \\
\hline
\end{tabular}

Abbreviations: DCs, dendritic cells; NKs, natural killer lymphocytes; Tregs, T regulatory lymphocytes; IL-1 $\beta$, interleukin- $1 \beta$; TGF- $\beta 1$, transforming growth factor- $\beta 1$; HGF, hepatocyte growth factor; $\mathrm{PGE}_{2}$, prostaglandin $\mathrm{E}_{2}$; IDO, indoleamine 2,3-dioxygenase; HO-1, heme oxygenase-1; LIF, leukemia inhibitory factor; IGF, insulinlike growth factor; HLA-G5, human leukocyte antigen G5; CCL1, CC chemokine ligand 1; M-CSF, macrophage-colony-stimulating factor.

of IL-1 $\beta$ and IL-10, regardless of CD86 expression [100]. BMMSCs also induce DCs to secrete IL-10, which favors IL-4-producing Th2 cells and Tregs [58]. Furthermore, BMMSCs impair the release of cytokines by activated DCs through $\mathrm{PGE}_{2}[58,99]$. Both cell-to-cell contact and soluble factors such as IL- 6 and macrophage-colony-stimulating factor (M-CSF) mediate the BMMSC-mediated inhibition of differentiation, cytokine production, and $\mathrm{T}$ cell stimulatory capacity of DCs $[98,101]$ (Table 1 ).

Interestingly, there are studies which show that BMMSCs itself can function as non-professional APCs. It has been reported that IFN- $\gamma$-stimulated BMMSCs can present exogenous antigens through upregulation of $\mathrm{MHC}$ class II molecules, which then results in activation of $\mathrm{CD}^{+}$ T cells [28,102-104]. BMMSCs can also cross-present exogenous antigens to induce $\mathrm{CD}^{+} \mathrm{T}$ cell proliferation $[105,106]$. A few studies have shown that BMMSCs-similar to DCs-express high levels of toll-like receptors (TLRs), including TLR1, TLR3, TLR4, and TLR5. TLRs are receptors primarily expressed on APCs which recognize conserved pathogen-derived components. Triggering of TLR3, which binds double-stranded RNA, and TLR4, which binds lipopolysaccharide (LPS) and innate self antigens, on BMMSCs has been reported to suppress the immunomodulation of these cells through Notch/Jagged1 signaling, leading to production of pro-inflammatory mediators such as IL-1 $\beta$, IL-6, and IL-8 [88,107-109]. However, another report showed that triggering of TLR on BMMSCs actually induces immunosuppression, which leads to the production of immunosuppressive kynurenines induced by IDO1. IDO1 can be induced by TLR3 and TLR4 signaling and this involves the activation of protein kinase $R$ (PKR), an autocrine IFN- $\beta$ signaling loop, and the activation of signal transducer and activator of transcription 1 (STAT1)/interferon regulatory factor 1 (IRF-1)[110]. These conflicting data regarding BMMSCs suppressing DC maturation and BMMSCs itself being an APC eliciting pro-inflammatory responses will require more research for clarification. One possible reason for these discrepant findings is that there is much heterogeneity between BMMSCs isolated from laboratory to laboratory. While the recent consensus of cell surface profile and tri-lineage mesodermal differentiation requirement has been extremely helpful to unify BMMSC phenotype [14], there still may exist epigenetic differences due to organ of origin and donor age, just to name a few variables. Moreover, the immunomodulatory properties of MSCs from different organs have not been much investigated, and one comparative study suggests that the MSC niche is unique in each tissue, which can contributes to functional differences [111]. Thus, it appears that studying the immunomodulatory behavior of MSCs derived from different origins would be important, and the accumulation 


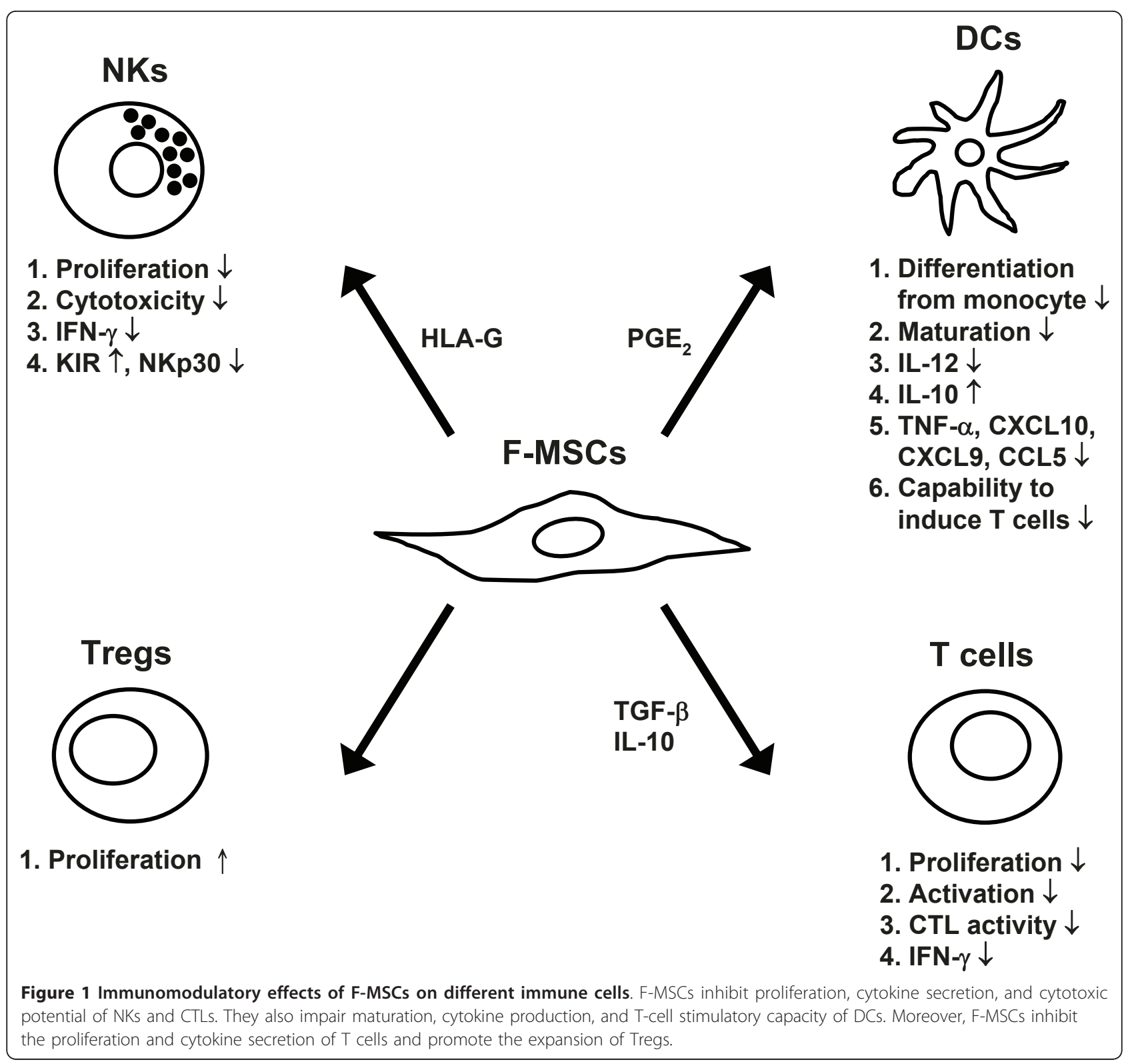

of such data will help to shed more light and clarity on discrepant findings of this field.

Some studies have suggested that F-MSCs are poor APCs due to their low or limited expression of MHC class II and co-stimulatory molecules even after IFN- $\gamma$ stimulation $[40,112]$. Recent studies have also investigated whether F-MSCs modulate DC phenotype and function. hAMSCs exert immunomodulatory effects on APCs, as demonstrated by their capacity to block maturation of monocytes into DCs [112]. They can prevent the expression of the DC lineage-specific marker CD1a and reduce the expression of HLA-DR, CD80, and CD83. This block in the monocyte-DC maturation process also results in impaired allostimulatory ability of these cells on allogeneic T cells [113,114]. Remarkably, hUCB-MSCs modulate DCs in a different way. hUCBMSCs suppress the function of mature DCs by driving DCs to an intermediate maturation state and boosting IL-12 production by mature DCs [115]. These inhibitory mechanisms involve both cell-contact dependent as well as secretion of soluble factors [50] (Figure 1).

3.3 Interactions with Natural Killer Lymphocytes (NKs)

NKs are key players of the innate immune system and are important in targeting virus-infected cells and tumor cells. NKs are highly cytotoxic and secrete large amounts of proinflammatory cytokines such as TNF- $\alpha$ and IFN- $\gamma[116,117]$. Part of the innate immune system, 
these cytotoxic lymphocytes are triggered to recognize and respond to MHC molecules signifying "self" versus "non-self", rather than specific antigens which $\mathrm{T}$ and $\mathrm{B}$ lymphocytes of the adaptive immune system recognize. A few studies have shown that BMMSCs are able to suppress the proliferation and cytokine production of NKs $[58,67,118]$. The inhibition requires both cell-tocell contact and soluble factors such as $\mathrm{PGE}_{2}$ and TGF$\beta[59,118]$. BMMSCs can also modulate the cytotoxicity of NKs, reducing the levels of NK-secreted cytokines such as IFN- $\gamma$, IL-10, and TNF- $\alpha$ and this phenomenon also requires cell-cell contact $[118,119]$. However, stimulated NKs can efficiently lyse autologous and allogeneic BMMSCs $[118,120,121]$. The activating NK receptors NKp30, NKG2D, and DNAM-1 were involved in NKmediated cytotoxicity against BMMSCs. IFN- $\gamma$-stimulated BMMSCs, on the other hand, were less susceptible to NK cell lysis as a consequence of the up-regulation of MHC class I molecules at the MSC surface [121]. Moreover, the secretion of soluble HLA-G (sHLA-G) by BMMSCs plays an important role in the inhibition of NK cytotoxicity and IFN- $\gamma$ release [74]. First identified in choriocarcinoma and migratory trophoblasts, HLA-G (non-classical MHC I molecule) is thought to confer for the fetus a protective effect against the maternal immune system, including directly suppressing maternal NK cytotoxicity [122]. HLA-G can exist in several forms, with the best characterized being the complete transmembrane form (HLA-G1)-the predominant in vivo form-and one of the three soluble, truncated forms (HLA-G5 or sHLA-G)[123]. Unlike most MHC I molecules, HLA-G has very low polymorphism and its expression in the adult is highly restricted; however, in certain pathologic states including cancer and inflammatory diseases, expression can be induced [124]. The receptors for HLA-G include ILT-2, ILT-4, and CD94 and these receptors can be found on a number of leukocytes, most prominently being NKs [125](Table 1).

F-MSCs can express surface molecule HLA-G, indicating potential tolerance-inducing properties $[51,126]$. We found that hP-MSCs are more resistant to stimulated-NK cytotoxicity than BMMSCs; moreover, hP-MSCs demonstrate enhanced suppressive effects towards NK in the presence of IFN- $\gamma$, and this is partially mediated through surface expression of HLA-G on hP-MSCs but not adult BMMSCs [127]. The placenta is known to have unique immunomodulatory interactions with maternal uterine NKs, which also have a different effector profile than peripheral blood NKs $[128,129]$. Thus, interactions of F-MSCs with NKs may be quite different than that found with BMMSCs, since NKs are one of the most important and predominant lymphocyte populations found during pregnancy. While such data is still scarce, research on F-MSCs interactions with this population of innate lymphocytes should yield interesting data, and perhaps even shed light on maternal-fetal immune mechanisms (Figure 1).

\section{Clinical applications of adult and F-MSCs for GVHD}

The majority of data on the immunomodulation of MSCs are in vitro in nature, however, a number of studies have been in vivo. One of the potentially lethal consequences after allogeneic HSCT is GVHD in which recipient cytotoxic $\mathrm{T}$ cells attack donor tissue, resulting in an immunerelated complication which is associated with high morbidity and mortality [130]. Animal models of GVHD are one of the most commonly used disease models to validate BMMSC immune function in vivo, and these studies have demonstrated that BMMSCs do remain immunomodulatory in vivo [131-134]. Recent data has shown that the combination of BMMSCs and immunosuppressive drugs can prolong organ allograft survival $[135,136]$. Because of the profound immunomodulatory effect of BMMSCs shown in vitro and in vivo, co-transplantation of ex vivo-expanded BMMSCs with HSCs for GVHD has been recommended [22,26,137-145]. In addition, cytokines released by BMMSCs may promote homing or proliferation of HSCs and enhance HSCs engraftment [146-151]. Thus, based on the accumulated in vitro and animal studies, a number of clinical trials have been started to evaluate the potential of BMMSCs for the treatment of GVHD $[22,26,137,140,152]$.

While there are in general fewer studies using F-MSCs as a cell therapy source, some pre-clinical studies have been conducted. Several animal studies show the prolonged survival of hAMSCs with no evidence of immunological rejection after xenogeneic transplantation into immunocompetent animals including rats [56,153-155] and swine [56]. Moreover, hAF-MSCs appear to be relatively resistant to rejection by the recipient-even with allogenic cell transplantation-due to the expression of immunosuppressive factors such as CD59 (protectin) and HLA-G [156]. Co-transplantation of UCBHSCs along with F-MSCs can reduce potential GVHD in recipients [35], as well as enhance UCB cell engraftment and homing of CD34 ${ }^{+}$HSCs $[157,158]$. Therefore, F-MSCs appear to be a promising source for stem cell therapy of GVHD and likely other immune-related diseases.

\section{Conclusions}

MSCs are multilineage progenitors which can be isolated from many adult organs as well as fetal-stage tissues. BMMSCs and F-MSCs have been reported to harbor strong immunomodulatory effects. While the data is still scarce regarding F-MSCs, several differences in the immune-suppressive properties between F-MSCs and adult BMMSCs have been found. Future investigations 
on the molecular mechanisms underlying the immunomodulatory properties of both F-MSCs and adult BMMSCs would be important since these differences may have functional relevance to therapeutic use of both sources of progenitor cells.

\section{Acknowledgements and Funding}

This work was supported by the National Science Council of Taiwan (grants NSC-99-3111-B-400-002, NSC 97-2320-B-400-005-MY3, and NSC-99-3112-B400-006 to B.L.Y.; and NSC-99-3111-B-002-009 to M.L.Y.)

\section{Author details}

'Regenerative Medicine Research Group, Institute of Cellular and System Medicine, National Health Research Institutes (NHRI), Zhunan, Taiwan.

${ }^{2}$ Department of Primary Care Medicine, and Department of Obstetrics/ Gynecology, College of Medicine, National Taiwan University and Hospital, Taipei, Taiwan. ${ }^{3}$ National Institute of Cancer Research, NHRI, Tainan, Taiwan. ${ }^{4}$ Graduate Institute of Microbiology and Immunology, National Defense Medical Center, Taipei, Taiwan. ${ }^{5}$ Department of Obstetrics/Gynecology, Cathay General Hospital Shiji, Taipei, Taiwan.

\section{Authors' contributions}

All authors have read and approved the final manuscript.

\section{Competing interests}

The authors declare that they have no competing interests.

Received: 29 April 2011 Accepted: 18 July 2011 Published: 18 July 2011

\section{References}

1. Pittenger MF, Mackay AM, Beck SC, Jaiswal RK, Douglas R, Mosca JD, Moorman MA, Simonetti DW, Craig S, Marshak DR: Multilineage potential of adult human mesenchymal stem cells. Science 1999, 284(5411):143-147.

2. Prockop DJ: Marrow stromal cells as stem cells for nonhematopoietic tissues. Science 1997, 276(5309):71-74

3. Friedenstein AJ, Petrakova KV, Kurolesova Al, Frolova GP: Heterotopic of bone marrow. Analysis of precursor cells for osteogenic and hematopoietic tissues. Transplantation 1968, 6(2):230-247.

4. Brooke G, Cook M, Blair C, Han R, Heazlewood C, Jones B, Kambouris M, Kollar K, McTaggart S, Pelekanos R, et al: Therapeutic applications of mesenchymal stromal cells. Semin Cell Dev Biol 2007, 18(6):846-858.

5. Zuk PA, Zhu M, Mizuno H, Huang J, Futrell JW, Katz AJ, Benhaim P, Lorenz HP, Hedrick MH: Multilineage cells from human adipose tissue: implications for cell-based therapies. Tissue Eng 2001, 7(2):211-228.

6. Sottile V, Halleux C, Bassilana F, Keller H, Seuwen K: Stem cell characteristics of human trabecular bone-derived cells. Bone 2002, 30(5):699-704.

7. Noth U, Osyczka AM, Tuli R, Hickok NJ, Danielson KG, Tuan RS: Multilineage mesenchymal differentiation potential of human trabecular bonederived cells. J Orthop Res 2002, 20(5):1060-1069.

8. Yen BL, Huang HI, Chien CC, Jui HY, Ko BS, Yao M, Shun $C T$, Yen ML, Lee MC, Chen YC: Isolation of multipotent cells from human term placenta. Stem Cells 2005, 23(1):3-9.

9. Lee OK, Kuo TK, Chen WM, Lee KD, Hsieh SL, Chen TH: Isolation of multipotent mesenchymal stem cells from umbilical cord blood. Blood 2004, 103(5):1669-1675.

10. Tsai MS, Lee JL, Chang YJ, Hwang SM: Isolation of human multipotent mesenchymal stem cells from second-trimester amniotic fluid using a novel two-stage culture protocol. Hum Reprod 2004, 19(6):1450-1456.

11. Wang HS, Hung SC, Peng ST, Huang CC, Wei HM, Guo YJ, Fu YS, Lai MC, Chen CC: Mesenchymal stem cells in the Wharton's jelly of the human umbilical cord. Stem Cells 2004, 22(7):1330-1337.

12. Gotherstrom C, Ringden O, Tammik C, Zetterberg E, Westgren M, Le Blanc K: Immunologic properties of human fetal mesenchymal stem cells. Am J Obstet Gynecol 2004, 190(1):239-245.

13. Campagnoli C, Roberts IA, Kumar S, Bennett PR, Bellantuono I, Fisk NM: Identification of mesenchymal stem/progenitor cells in human first- trimester fetal blood, liver, and bone marrow. Blood 2001 98(8):2396-2402

14. Dominici M, Le Blanc K, Mueller I, Slaper-Cortenbach I, Marini F, Krause D, Deans R, Keating A, Prockop D, Horwitz E: Minimal criteria for defining multipotent mesenchymal stromal cells. The International Society for Cellular Therapy position statement. Cytotherapy 2006, 8(4):315-317.

15. Picinich SC, Mishra PJ, Mishra PJ, Glod J, Banerjee D: The therapeutic potential of mesenchymal stem cells. Cell- \& tissue-based therapy. Expert Opin Biol Ther 2007, 7(7):965-973.

16. Giordano A, Galderisi U, Marino IR: From the laboratory bench to the patient's bedside: an update on clinical trials with mesenchymal stem cells. J Cell Physiol 2007, 211(1):27-35.

17. Bartholomew A, Sturgeon C, Siatskas M, Ferrer K, McIntosh K, Patil S, Hardy W, Devine S, Ucker D, Deans R, et al: Mesenchymal stem cells suppress lymphocyte proliferation in vitro and prolong skin graft survival in vivo. Exp Hematol 2002, 30(1):42-48

18. Le Blanc K, Tammik C, Rosendahl K, Zetterberg E, Ringden O: HLA expression and immunologic properties of differentiated and undifferentiated mesenchymal stem cells. Exp Hematol 2003, 31(10):890-896.

19. Di Nicola M, Carlo-Stella C, Magni M, Milanesi M, Longoni PD, Matteucci P, Grisanti S, Gianni AM: Human bone marrow stromal cells suppress Tlymphocyte proliferation induced by cellular or nonspecific mitogenic stimuli. Blood 2002, 99(10):3838-3843.

20. Dean RM, Bishop MR: Graft-versus-host disease: emerging concepts in prevention and therapy. Curr Hematol Rep 2003, 2(4):287-294.

21. Barker JN, Wagner JE: Umbilical cord blood transplantation: current practice and future innovations. Crit Rev Oncol Hematol 2003, 48(1):35-43.

22. Le Blanc K, Frassoni F, Ball L, Locatelli F, Roelofs H, Lewis I, Lanino E, Sundberg B, Bernardo ME, Remberger $M$, et al: Mesenchymal stem cells for treatment of steroid-resistant, severe, acute graft-versus-host disease: a phase II study. Lancet 2008, 371(9624):1579-1586.

23. Jurewicz M, Yang S, Augello A, Godwin JG, Moore RF, Azzi J, Fiorina P, Atkinson M, Sayegh MH, Abdi R: Congenic mesenchymal stem cel therapy reverses hyperglycemia in experimental type 1 diabetes. Diabetes 2010, 59(12):3139-3147.

24. Nemeth K, Leelahavanichkul A, Yuen PS, Mayer B, Parmelee A, Doi K, Robey PG, Leelahavanichkul K, Koller BH, Brown JM, et al: Bone marrow stromal cells attenuate sepsis via prostaglandin $\mathrm{E}_{2}$-dependent reprogramming of host macrophages to increase their interleukin-10 production. Nat Med 2009, 15(1):42-49.

25. Augello A, Tasso R, Negrini SM, Cancedda R, Pennesi G: Cell therapy using allogeneic bone marrow mesenchymal stem cells prevents tissue damage in collagen-induced arthritis. Arthritis Rheum 2007, 56(4):1175-1186.

26. Le Blanc K, Rasmusson I, Sundberg B, Gotherstrom C, Hassan M, Uzunel M, Ringden O: Treatment of severe acute graft-versus-host disease with third party haploidentical mesenchymal stem cells. Lancet 2004, 363(9419):1439-1441.

27. Barry FP, Murphy JM, English K, Mahon BP: Immunogenicity of adult mesenchymal stem cells: lessons from the fetal allograft. Stem Cells Dev 2005, 14(3):252-265.

28. Majumdar MK, Keane-Moore M, Buyaner D, Hardy WB, Moorman MA, McIntosh KR, Mosca JD: Characterization and functionality of cell surface molecules on human mesenchymal stem cells. J Biomed Sci 2003, 10(2):228-241.

29. Tse WT, Pendleton JD, Beyer WM, Egalka MC, Guinan EC: Suppression of allogeneic T-cell proliferation by human marrow stromal cells: implications in transplantation. Transplantation 2003, 75(3):389-397.

30. Klyushnenkova E, Mosca JD, Zernetkina V, Majumdar MK, Beggs KJ, Simonetti DW, Deans RJ, Mclntosh KR: T cell responses to allogeneic human mesenchymal stem cells: immunogenicity, tolerance, and suppression. J Biomed Sci 2005, 12(1):47-57.

31. Stenderup K, Justesen J, Clausen C, Kassem M: Aging is associated with decreased maximal life span and accelerated senescence of bone marrow stromal cells. Bone 2003, 33(6):919-926.

32. de Braud F, Khayat D, Kroon BB, Valdagni R, Bruzzi P, Cascinelli N. Malignant melanoma. Crit Rev Oncol Hematol 2003, 47(1):35-63.

33. Erices $\mathrm{A}$, Conget $\mathrm{P}$, Minguell $\mathrm{J}$ : Mesenchymal progenitor cells in human umbilical cord blood. Br J Haematol 2000, 109(1):235-242.

34. Sarugaser R, Lickorish D, Baksh D, Hosseini MM, Davies JE: Human umbilical cord perivascular (HUCPV) cells: a source of mesenchymal progenitors. Stem Cells 2005, 23(2):220-229. 
35. In 't Anker PS, Scherjon SA, Kleijburg-van der Keur C, Noort WA, Claas FH, Willemze R, Fibbe WE, Kanhai HH: Amniotic fluid as a novel source of mesenchymal stem cells for therapeutic transplantation. Blood 2003, 102(4):1548-1549.

36. Bachmann MF, Kohler G, Ecabert B, Mak TW, Kopf M: Lymphoproliferative disease in the absence of CTLA-4 is not T cell autonomous. J Immunol 1999, 163(3):1128-1131.

37. Fukuchi Y, Nakajima H, Sugiyama D, Hirose I, Kitamura T, Tsuji K: Human placenta-derived cells have mesenchymal stem/progenitor cell potential. Stem Cells 2004, 22(5):649-658.

38. Wulf GG, Viereck V, Hemmerlein B, Haase D, Vehmeyer K, Pukrop T, Glass B, Emons $G$, Trumper $L$ : Mesengenic progenitor cells derived from human placenta. Tissue Eng 2004, 10(7-8):1136-1147.

39. In 't Anker PS, Scherjon SA, Kleijburg-van der Keur C, de Groot-Swings GM, Claas FH, Fibbe WE, Kanhai HH: Isolation of mesenchymal stem cells of fetal or maternal origin from human placenta. Stem Cells 2004, 22(7):1338-1345.

40. Chang CJ, Yen ML, Chen YC, Chien CC, Huang HI, Bai CH, Yen BL: Placentaderived multipotent cells exhibit immunosuppressive properties that are enhanced in the presence of interferon-gamma. Stem Cells 2006, 24(11):2466-2477.

41. Chiavegato A, Bollini S, Pozzobon M, Callegari A, Gasparotto L, Taiani J, Piccoli M, Lenzini E, Gerosa G, Vendramin I, et al: Human amniotic fluidderived stem cells are rejected after transplantation in the myocardium of normal, ischemic, immuno-suppressed or immuno-deficient rat. J Mol Cell Cardiol 2007, 42(4):746-759.

42. Hao L, Zhang C, Chen XH, Zou ZM, Zhang X, Kong PY, Liang X, Gao L, Peng $X G$, Sun $A H$, et al: Human umbilical cord blood-derived stromal cells suppress xenogeneic immune cell response in vitro. Croat Med J 2009, 50(4):351-360.

43. Ilancheran S, Michalska A, Peh G, Wallace EM, Pera M, Manuelpillai U: Stem cells derived from human fetal membranes display multilineage differentiation potential. Biol Reprod 2007, 77(3):577-588.

44. Kim J, Lee Y, Kim H, Hwang KJ, Kwon HC, Kim SK, Cho DJ, Kang SG, You J: Human amniotic fluid-derived stem cells have characteristics of multipotent stem cells. Cell Prolif 2007, 40(1):75-90.

45. Lu LL, Liu YJ, Yang SG, Zhao QJ, Wang X, Gong W, Han ZB, Xu ZS, Lu YX, Liu $D$, et al: Isolation and characterization of human umbilical cord mesenchymal stem cells with hematopoiesis-supportive function and other potentials. Haematologica 2006, 91(8):1017-1026.

46. Oh W, Kim DS, Yang YS, Lee JK: Immunological properties of umbilical cord blood-derived mesenchymal stromal cells. Cell Immunol 2008, 251(2):116-123.

47. Portmann-Lanz CB, Schoeberlein A, Huber A, Sager R, Malek A, Holzgreve W, Surbek DV: Placental mesenchymal stem cells as potential autologous graft for pre- and perinatal neuroregeneration. Am J Obstet Gynecol 2006, 194(3):664-673.

48. Roubelakis MG, Pappa Kl, Bitsika V, Zagoura D, Vlahou A, Papadaki HA, Antsaklis A, Anagnou NP: Molecular and proteomic characterization of human mesenchymal stem cells derived from amniotic fluid: comparison to bone marrow mesenchymal stem cells. Stem Cells Dev 2007, 16(6):931-952.

49. Terada S, Matsuura K, Enosawa S, Miki M, Hoshika A, Suzuki S, Sakuragawa N: Inducing proliferation of human amniotic epithelial (HAE) cells for cell therapy. Cell Transplant 2000, 9(5):701-704.

50. Wang M, Yang Y, Yang D, Luo F, Liang W, Guo S, Xu J: The immunomodulatory activity of human umbilical cord blood-derived mesenchymal stem cells in vitro. Immunology 2009, 126(2):220-232.

51. Weiss ML, Anderson C, Medicetty S, Seshareddy KB, Weiss RJ, VanderWerff I, Troyer D, McIntosh KR: Immune properties of human umbilical cord Wharton's jelly-derived cells. Stem Cells 2008, 26(11):2865-2874.

52. Weiss ML, Medicetty S, Bledsoe AR, Rachakatla RS, Choi M, Merchav S, Luo Y, Rao MS, Velagaleti G, Troyer D: Human umbilical cord matrix stem cells: preliminary characterization and effect of transplantation in a rodent model of Parkinson's disease. Stem Cells 2006, 24(3):781-792.

53. Li C, Zhang W, Jiang X, Mao N: Human-placenta-derived mesenchymal stem cells inhibit proliferation and function of allogeneic immune cells Cell Tissue Res 2007, 330(3):437-446.

54. Wolbank S, Peterbauer A, Fahrner M, Hennerbichler S, van Griensven M, Stadler G, Redl H, Gabriel C: Dose-dependent immunomodulatory effect of human stem cells from amniotic membrane: a comparison with human mesenchymal stem cells from adipose tissue. Tissue Eng 2007, 13(6):1173-1183.

55. Magatti M, De Munari S, Vertua E, Gibelli L, Wengler GS, Parolini O: Human amnion mesenchyme harbors cells with allogeneic T-cell suppression and stimulation capabilities. Stem Cells 2008, 26(1):182-192.

56. Bailo M, Soncini M, Vertua E, Signoroni PB, Sanzone S, Lombardi G, Arienti D, Calamani F, Zatti D, Paul P, et al: Engraftment potential of human amnion and chorion cells derived from term placenta. Transplantation 2004, 78(10):1439-1448.

57. Li H, Niederkorn JY, Neelam S, Mayhew E, Word RA, McCulley JP, Alizadeh H: Immunosuppressive factors secreted by human amniotic epithelial cells. Invest Ophthalmol Vis Sci 2005, 46(3):900-907.

58. Aggarwal S, Pittenger MF: Human mesenchymal stem cells modulate allogeneic immune cell responses. Blood 2005, 105(4):1815-1822.

59. Krampera M, Cosmi L, Angeli R, Pasini A, Liotta F, Andreini A, Santarlasci V, Mazzinghi B, Pizzolo G, Vinante F, et al: Role for interferon-gamma in the immunomodulatory activity of human bone marrow mesenchymal stem cells. Stem Cells 2006, 24(2):386-398.

60. Krampera M, Glennie S, Dyson J, Scott D, Laylor R, Simpson E, Dazzi F: Bone marrow mesenchymal stem cells inhibit the response of naive and memory antigen-specific T cells to their cognate peptide. Blood 2003, 101(9):3722-3729.

61. Glennie S, Soeiro I, Dyson PJ, Lam EW, Dazzi F: Bone marrow mesenchymal stem cells induce division arrest anergy of activated $T$ cells. Blood 2005, 105(7):2821-2827.

62. Benvenuto F, Ferrari S, Gerdoni E, Gualandi F, Frassoni F, Pistoia V, Mancardi G, Uccelli A: Human mesenchymal stem cells promote survival of T cells in a quiescent state. Stem Cells 2007, 25(7):1753-1760.

63. Zhou L, Chong MM, Littman DR: Plasticity of $\mathrm{CD}^{+} \mathrm{T}$ cell lineage differentiation. Immunity 2009, 30(5):646-655.

64. Bai L, Lennon DP, Eaton V, Maier K, Caplan Al, Miller SD, Miller RH: Human bone marrow-derived mesenchymal stem cells induce Th2-polarized immune response and promote endogenous repair in animal models of multiple sclerosis. Glia 2009, 57(11):1192-1203.

65. Rafei M, Campeau PM, Aguilar-Mahecha A, Buchanan M, Williams P, Birman E, Yuan S, Young YK, Boivin MN, Forner K, et al: Mesenchymal stromal cells ameliorate experimental autoimmune encephalomyelitis by inhibiting CD4 Th17 T cells in a CC chemokine ligand 2-dependent manner. J Immunol 2009, 182(10):5994-6002.

66. Ghannam S, Pene J, Torcy-Moquet G, Jorgensen C, Yssel H: Mesenchymal stem cells inhibit human Th17 cell differentiation and function and induce a T regulatory cell phenotype. J Immunol 2010, 185(1):302-312.

67. Maccario R, Podesta M, Moretta A, Cometa A, Comoli P, Montagna D, Daudt L, Ibatici A, Piaggio G, Pozzi S, et al: Interaction of human mesenchymal stem cells with cells involved in alloantigen-specific immune response favors the differentiation of $\mathrm{CD}^{+} \mathrm{T}$-cell subsets expressing a regulatory/suppressive phenotype. Haematologica 2005, 90(4):516-525.

68. Riley $\mathrm{L}$, June $\mathrm{CH}$, Blazar BR: Human T regulatory cell therapy: take a billion or so and call me in the morning. Immunity 2009, 30(5):656-665.

69. Shevach EM: Mechanisms of foxp $3^{+} \mathrm{T}$ regulatory cell-mediated suppression. Immunity 2009, 30(5):636-645.

70. Itoh M, Takahashi T, Sakaguchi N, Kuniyasu Y, Shimizu J, Otsuka F, Sakaguchi S: Thymus and autoimmunity: production of $\mathrm{CD} 25^{+} \mathrm{CD} 4^{+}$ naturally anergic and suppressive $T$ cells as a key function of the thymus in maintaining immunologic self-tolerance. J Immunol 1999, 162(9):5317-5326.

71. English K, Ryan JM, Tobin L, Murphy MJ, Barry FP, Mahon BP: Cell contact, prostaglandin $E_{2}$ and transforming growth factor beta 1 play nonredundant roles in human mesenchymal stem cell induction of CD4 ${ }^{+} \mathrm{CD} 25^{\text {High }}$ forkhead box $\mathrm{P}^{+}$regulatory T cells. Clin Exp Immunol 2009, 156(1):149-160.

72. Prevosto C, Zancolli M, Canevali P, Zocchi MR, Poggi A: Generation of CD4 ${ }^{+}$or $\mathrm{CD}^{+}$regulatory T cells upon mesenchymal stem cell-lymphocyte interaction. Haematologica 2007, 92(7):881-888.

73. Di lanni M, Del Papa B, De loanni M, Moretti L, Bonifacio E, Cecchini D, Sportoletti $P$, Falzetti F, Tabilio A: Mesenchymal cells recruit and regulate T regulatory cells. Exp Hematol 2008, 36(3):309-318.

74. Selmani Z, Naji A, Zidi I, Favier B, Gaiffe E, Obert L, Borg C, Saas P, Tiberghien P, Rouas-Freiss N, et al: Human leukocyte antigen-G5 secretion by human mesenchymal stem cells is required to suppress $T$ 
lymphocyte and natural killer function and to induce CD4 ${ }^{+} \mathrm{CD} 25^{\text {high }} \mathrm{FOXP3}^{+}$regulatory T cells. Stem Cells 2008, 26(1):212-222.

75. Batten P, Sarathchandra P, Antoniw JW, Tay SS, Lowdell MW, Taylor PM, Yacoub MH: Human mesenchymal stem cells induce T cell anergy and downregulate $\mathrm{T}$ cell allo-responses via the $\mathrm{TH} 2$ pathway: relevance to tissue engineering human heart valves. Tissue Eng 2006, 12(8):2263-2273.

76. Rasmusson I: Immune modulation by mesenchymal stem cells. Exp Cell Res 2006, 312(12):2169-2179.

77. Groh ME, Maitra B, Szekely E, Koc ON: Human mesenchymal stem cells require monocyte-mediated activation to suppress alloreactive $\mathrm{T}$ cells. Exp Hematol 2005, 33(8):928-934.

78. Rasmusson I, Ringden O, Sundberg B, Le Blanc K: Mesenchymal stem cells inhibit lymphocyte proliferation by mitogens and alloantigens by different mechanisms. Exp Cell Res 2005, 305(1):33-41.

79. Ryan JM, Barry F, Murphy JM, Mahon BP: Interferon-gamma does not break, but promotes the immunosuppressive capacity of adult human mesenchymal stem cells. Clin Exp Immunol 2007, 149(2):353-363.

80. Meisel R, Zibert A, Laryea M, Gobel U, Daubener W, Dilloo D: Human bone marrow stromal cells inhibit allogeneic T-cell responses by indoleamine 2,3-dioxygenase-mediated tryptophan degradation. Blood 2004 103(12):4619-4621.

81. Plumas J, Chaperot L, Richard MJ, Molens JP, Bensa JC, Favrot MC Mesenchymal stem cells induce apoptosis of activated T cells. Leukemia 2005, 19(9):1597-1604.

82. Chabannes D, Hill M, Merieau E, Rossignol J, Brion R, Soulillou JP, Anegon I, Cuturi MC: A role for heme oxygenase-1 in the immunosuppressive effect of adult rat and human mesenchymal stem cells. Blood 2007, 110(10):3691-3694.

83. Nasef A, Mazurier C, Bouchet S, Francois S, Chapel A, Thierry D, Gorin NC, Fouillard L: Leukemia inhibitory factor: Role in human mesenchymal stem cells mediated immunosuppression. Cell Immunol 2008, 253(12):16-22.

84. Gieseke F, Schutt B, Viebahn S, Koscielniak E, Friedrich W, Handgretinger R, Muller I: Human multipotent mesenchymal stromal cells inhibit proliferation of PBMCs independently of IFNgammaR1 signaling and IDO expression. Blood 2007, 110(6):2197-2200.

85. Nasef A, Mathieu N, Chapel A, Frick J, Francois S, Mazurier C, Boutarfa A, Bouchet S, Gorin NC, Thierry D, et al: Immunosuppressive effects of mesenchymal stem cells: involvement of HLA-G. Transplantation 2007, 84(2):231-237

86. Gieseke F, Bohringer J, Bussolari R, Dominici M, Handgretinger R, Muller I: Human multipotent mesenchymal stromal cells use galectin-1 to inhibit immune effector cells. Blood 2010, 116(19):3770-3779.

87. Sioud M, Mobergslien A, Boudabous A, Floisand Y: Mesenchymal stem cell-mediated T cell suppression occurs through secreted galectins. Int J Oncol 2011, 38(2):385-390.

88. Liotta F, Angeli R, Cosmi L, Fili L, Manuelli C, Frosali F, Mazzinghi B, Maggi L, Pasini A, Lisi V, et al: Toll-like receptors 3 and 4 are expressed by human bone marrow-derived mesenchymal stem cells and can inhibit their T-cell modulatory activity by impairing Notch signaling. Stem Cells 2008, 26(1):279-289

89. Wang D, Chen K, Du WT, Han ZB, Ren H, Chi Y, Yang SG, Bayard F, Zhu D, Han ZC: CD14 $4^{+}$monocytes promote the immunosuppressive effect of human umbilical cord matrix stem cells. Exp Cell Res 2010, 316(15):2414-2423.

90. Cutler AJ, Limbani V, Girdlestone J, Navarrete CV: Umbilical cord-derived mesenchymal stromal cells modulate monocyte function to suppress T cell proliferation. J Immunol 2010, 185(11):6617-6623.

91. Chen K, Wang D, Du WT, Han ZB, Ren H, Chi Y, Yang SG, Zhu D, Bayard F, Han ZC: Human umbilical cord mesenchymal stem cells hUC-MSCs exert immunosuppressive activities through a $\mathrm{PGE}_{2}$-dependent mechanism. Clin Immunol 2010, 135(3):448-458.

92. Girdlestone J, Limbani VA, Cutler AJ, Navarrete CV: Efficient expansion of mesenchymal stromal cells from umbilical cord under low serum conditions. Cytotherapy 2009, 11(6):738-748.

93. Zhang Y, Li C, Jiang X, Zhang S, Wu Y, Liu B, Tang P, Mao N: Human placenta-derived mesenchymal progenitor cells support culture expansion of long-term culture-initiating cells from cord blood CD34 $4^{+}$ cells. Exp Hematol 2004, 32(7):657-664.

94. Roelen DL, van der Mast BJ, in't Anker PS, Kleijburg C, Eikmans M, van Beelen E, de Groot-Swings GM, Fibbe WE, Kanhai HH, Scherjon SA, et al:
Differential immunomodulatory effects of fetal versus maternal multipotent stromal cells. Hum Immunol 2009, 70(1):16-23.

95. Prasanna SJ, Gopalakrishnan D, Shankar SR, Vasandan AB: Pro-inflammatory cytokines, IFNgamma and TNFalpha, influence immune properties of human bone marrow and Wharton jelly mesenchymal stem cells differentially. PLoS One 2010, 5(2):e9016..

96. Jones EY, Fugger L, Strominger JL, Siebold C: MHC class II proteins and disease: a structural perspective. Nat Rev Immunol 2006, 6(4):271-282.

97. Steinman RM, Pack M, Inaba K: Dendritic cells in the T-cell areas of lymphoid organs. Immunol Rev 1997, 156:25-37.

98. Jiang XX, Zhang Y, Liu B, Zhang SX, Wu Y, Yu XD, Mao N: Human mesenchymal stem cells inhibit differentiation and function of monocyte-derived dendritic cells. Blood 2005, 105(10):4120-4126.

99. Spaggiari GM, Abdelrazik H, Becchetti F, Moretta L: MSCs inhibit monocyte-derived DC maturation and function by selectively interfering with the generation of immature DCs: central role of MSC-derived prostaglandin $E_{2}$. Blood 2009, 113(26):6576-6583.

100. Beyth S, Borovsky Z, Mevorach D, Liebergall M, Gazit Z, Aslan H, Galun E, Rachmilewitz J: Human mesenchymal stem cells alter antigen-presenting cell maturation and induce T-cell unresponsiveness. Blood 2005, 105(5):2214-2219.

101. Li YP, Paczesny S, Lauret E, Poirault S, Bordigoni P, Mekhloufi F, Hequet $\mathrm{O}$, Bertrand Y, Ou-Yang JP, Stoltz JF, et al: Human mesenchymal stem cells license adult $\mathrm{CD} 34^{+}$hemopoietic progenitor cells to differentiate into regulatory dendritic cells through activation of the Notch pathway. J Immunol 2008, 180(3):1598-1608.

102. Chan WK, Lau AS, Li JC, Law HK, Lau YL, Chan GC: MHC expression kinetics and immunogenicity of mesenchymal stromal cells after shortterm IFN-gamma challenge. Exp Hematol 2008, 36(11):1545-1555.

103. Stagg J, Pommey S, Eliopoulos N, Galipeau J: Interferon-gamma-stimulated marrow stromal cells: a new type of nonhematopoietic antigenpresenting cell. Blood 2006, 107(6):2570-2577.

104. Chan JL, Tang KC, Patel AP, Bonilla LM, Pierobon N, Ponzio NM, Rameshwar P: Antigen-presenting property of mesenchymal stem cells occurs during a narrow window at low levels of interferon-gamma. Blood 2006, 107(12):4817-4824.

105. Francois M, Romieu-Mourez R, Stock-Martineau S, Boivin MN, Bramson JL, Galipeau J: Mesenchymal stromal cells cross-present soluble exogenous antigens as part of their antigen-presenting cell properties. Blood 2009, 114(13):2632-2638.

106. Morandi F, Raffaghello L, Bianchi G, Meloni F, Salis A, Millo E, Ferrone S, Barnaba V, Pistoia V: Immunogenicity of human mesenchymal stem cells in HLA-class I-restricted T-cell responses against viral or tumorassociated antigens. Stem Cells 2008, 26(5):1275-1287.

107. Romieu-Mourez R, Francois M, Boivin MN, Bouchentouf M, Spaner DE, Galipeau J: Cytokine modulation of TLR expression and activation in mesenchymal stromal cells leads to a proinflammatory phenotype. J Immunol 2009, 182(12):7963-7973.

108. Pevsner-Fischer M, Morad V, Cohen-Sfady M, Rousso-Noori L, ZaninZhorov A, Cohen S, Cohen IR, Zipori D: Toll-like receptors and their ligands control mesenchymal stem cell functions. Blood 2007, 109(4):1422-1432.

109. Tomchuck SL, Zwezdaryk KJ, Coffelt SB, Waterman RS, Danka ES, Scandurro AB: Toll-like receptors on human mesenchymal stem cells drive their migration and immunomodulating responses. Stem Cells 2008, 26(1):99-107.

110. Opitz CA, Litzenburger UM, Lutz C, Lanz TV, Tritschler I, Koppel A, Tolosa E, Hoberg M, Anderl J, Aicher WK, et al: Toll-like receptor engagement enhances the immunosuppressive properties of human bone marrowderived mesenchymal stem cells by inducing indoleamine-2,3dioxygenase-1 via interferon-beta and protein kinase R. Stem Cells 2009, 27(4):909-919.

111. Kern S, Eichler H, Stoeve J, Kluter H, Bieback K: Comparative analysis of mesenchymal stem cells from bone marrow, umbilical cord blood, or adipose tissue. Stem Cells 2006, 24(5):1294-1301.

112. Parolini O, Alviano F, Bagnara GP, Bilic G, Buhring HJ, Evangelista M, Hennerbichler S, Liu B, Magatti M, Mao N, et al: Isolation and characterization of cells from human term placenta: outcome of the first international Workshop on Placenta Derived Stem Cells. Stem Cells 2008, 26(2):300-311. 
113. Magatti M, De Munari S, Vertua E, Nassauto C, Albertini A, Wengler GS, Parolini O: Amniotic mesenchymal tissue cells inhibit dendritic cell differentiation of peripheral blood and amnion resident monocytes. Cell Transplant 2009, 18(8):899-914.

114. Kronsteiner B, Peterbauer-Scherb A, Grillari-Voglauer R, Redl H, Gabriel C, van Griensven M, Wolbank S: Human mesenchymal stem cells and renal tubular epithelial cells differentially influence monocyte-derived dendritic cell differentiation and maturation. Cell Immunol 2011, 267(1):30-38.

115. van den Berk LC, Roelofs H, Huijs T, Siebers-Vermeulen KG, Raymakers RA, Kogler G, Figdor CG, Torensma R: Cord blood mesenchymal stem cells propel human dendritic cells to an intermediate maturation state and boost interleukin-12 production by mature dendritic cells. Immunology 2009, 128(4):564-572

116. Moretta A, Locatelli F, Moretta L: Human NK cells: from HLA class Ispecific killer lg-like receptors to the therapy of acute leukemias. Immunol Rev 2008, 224:58-69.

117. Caligiuri MA: Human natural killer cells. Blood 2008, 112(3):461-469.

118. Sotiropoulou PA, Perez SA, Gritzapis AD, Baxevanis CN, Papamichail M: Interactions between human mesenchymal stem cells and natural killer cells. Stem Cells 2006, 24(1):74-85.

119. Spaggiari GM, Capobianco A, Abdelrazik H, Becchetti F, Mingari MC, Moretta L: Mesenchymal stem cells inhibit natural killer-cell proliferation, cytotoxicity, and cytokine production: role of indoleamine 2,3dioxygenase and prostaglandin $\mathrm{E}_{2}$. Blood 2008, 111(3):1327-1333.

120. Poggi A, Zocchi MR: Antigen presenting cells and stromal cells trigger human natural killer lymphocytes to autoreactivity: evidence for the involvement of natural cytotoxicity receptors (NCR) and NKG2D. Clin Dev Immunol 2006, 13(2-4):325-336.

121. Spaggiari GM, Capobianco A, Becchetti S, Mingari MC, Moretta L: Mesenchymal stem cell-natural killer cell interactions: evidence that activated NK cells are capable of killing MSCs, whereas MSCs can inhibit IL-2-induced NK-cell proliferation. Blood 2006, 107(4):1484-1490.

122. Rouas-Freiss N, Goncalves RM, Menier C, Dausset J, Carosella ED: Direct evidence to support the role of HLA-G in protecting the fetus from maternal uterine natural killer cytolysis. Proc Natl Acad Sci USA 1997 94(21):11520-11525.

123. Apps R, Gardner L, Moffett A: A critical look at HLA-G. Trends Immunol 2008, 29(7):313-321.

124. Carosella ED, Favier B, Rouas-Freiss N, Moreau P, Lemaoult J: Beyond the increasing complexity of the immunomodulatory HLA-G molecule. Blood 2008, 111(10):4862-4870.

125. LeMaoult J, Zafaranloo K, Le Danff C, Carosella ED: HLA-G up-regulates ILT2, ILT3, ILT4, and KIR2DL4 in antigen presenting cells, NK cells, and T cells. FASEB J 2005, 19(6):662-664

126. La Rocca G, Anzalone R, Corrao S, Magno F, Loria T, Lo lacono M, Di Stefano A, Giannuzzi P, Marasa L, Cappello F, et al: Isolation and characterization of Oct- $4^{+} / \mathrm{HLA}-\mathrm{G}^{+}$mesenchymal stem cells from human umbilical cord matrix: differentiation potential and detection of new markers. Histochem Cell Biol 2009, 131(2):267-282.

127. Liu KJ, Wang JC, Chang CJ, Hu HI, Hsu PJ, Wu YC, Bai CH, Sytwu HK, Yen BL: Surface expression of HLA-G is involved in mediating immunomodulatory effects of placenta-derived multipotent cells (PDMCs) towards natural killer lymphocytes. Cell Transplant 2011.

128. Gaunt G, Ramin K: Immunological tolerance of the human fetus. Am J Perinatol 2001, 18(6):299-312

129. Moffett-King A: Natural killer cells and pregnancy. Nat Rev Immunol 2002, 2(9):656-663

130. Deeg HJ: How I treat refractory acute GVHD. Blood 2007 109(10):4119-4126

131. Aksu AE, Horibe E, Sacks J, Ikeguchi R, Breitinger J, Scozio M, Unadkat J, Feili-Hariri M: Co-infusion of donor bone marrow with host mesenchymal stem cells treats GVHD and promotes vascularized skin allograft survival in rats. Clin Immunol 2008, 127(3):348-358.

132. Zhou HP, Yi DH, Yu SQ, Sun GC, Cui Q, Zhu HL, Liu JC, Zhang JZ, Wu TJ: Administration of donor-derived mesenchymal stem cells can prolong the survival of rat cardiac allograft. Transplant Proc 2006, 38(9):3046-3051.

133. Yanez R, Lamana ML, Garcia-Castro J, Colmenero I, Ramirez M, Bueren JA: Adipose tissue-derived mesenchymal stem cells have in vivo immunosuppressive properties applicable for the control of the graftversus-host disease. Stem Cells 2006, 24(11):2582-2591.
134. Kim DW, Chung YJ, Kim TG, Kim YL, Oh IH: Cotransplantation of thirdparty mesenchymal stromal cells can alleviate single-donor predominance and increase engraftment from double cord transplantation. Blood 2004, 103(5):1941-1948.

135. Ge W, Jiang J, Baroja ML, Arp J, Zassoko R, Liu W, Bartholomew A, Garcia B, Wang $\mathrm{H}$ : Infusion of mesenchymal stem cells and rapamycin synergize to attenuate alloimmune responses and promote cardiac allograft tolerance. Am J Transplant 2009, 9(8):1760-1772.

136. Popp FC, Eggenhofer E, Renner P, Slowik P, Lang SA, Kaspar H, Geissler EK, Piso $P$, Schlitt HJ, Dahlke MH: Mesenchymal stem cells can induce longterm acceptance of solid organ allografts in synergy with low-dose mycophenolate. Transpl Immunol 2008, 20(1-2):55-60.

137. von Bonin M, Stolzel F, Goedecke A, Richter K, Wuschek N, Holig K, Platzbecker U, IIImer T, Schaich M, Schetelig J, et al: Treatment of refractory acute GVHD with third-party MSC expanded in platelet lysatecontaining medium. Bone Marrow Transplant 2009, 43(3):245-251.

138. Fang B, Song $Y$, Liao L, Zhang $Y$, Zhao RC: Favorable response to human adipose tissue-derived mesenchymal stem cells in steroid-refractory acute graft-versus-host disease. Transplant Proc 2007, 39(10):3358-3362.

139. Muller I, Kordowich S, Holzwarth C, Isensee G, Lang P, Neunhoeffer F, Dominici M, Greil J, Handgretinger R: Application of multipotent mesenchymal stromal cells in pediatric patients following allogeneic stem cell transplantation. Blood Cells Mol Dis 2008, 40(1):25-32

140. Lazarus HM, Koc ON, Devine SM, Curtin P, Maziarz RT, Holland HK, Shpall EJ, McCarthy P, Atkinson K, Cooper BW, et al: Cotransplantation of HLAidentical sibling culture-expanded mesenchymal stem cells and hematopoietic stem cells in hematologic malignancy patients. Biol Blood Marrow Transplant 2005, 11(5):389-398.

141. Ning $H$, Yang $F$, Jiang $M$, Hu L, Feng $K$, Zhang J, Yu Z, Li B, Xu C, Li Y, et al: The correlation between cotransplantation of mesenchymal stem cells and higher recurrence rate in hematologic malignancy patients: outcome of a pilot clinical study. Leukemia 2008, 22(3):593-599.

142. Taupin P: OTI-010 Osiris Therapeutics/JCR Pharmaceuticals. Curr Opin Investig Drugs 2006, 7(5):473-481.

143. Vianello F, Dazzi F: Mesenchymal stem cells for graft-versus-host disease: a double edged sword? Leukemia 2008, 22(3):463-465.

144. Sundin M, Ringden O, Sundberg B, Nava S, Gotherstrom C, Le Blanc K: No alloantibodies against mesenchymal stromal cells, but presence of antifetal calf serum antibodies, after transplantation in allogeneic hematopoietic stem cell recipients. Haematologica 2007, 92(9):1208-1215.

145. Le Blanc K, Ringden O: Immunobiology of human mesenchymal stem cells and future use in hematopoietic stem cell transplantation. Biol Blood Marrow Transplant 2005, 11(5):321-334.

146. Eliopoulos N, Stagg J, Lejeune L, Pommey S, Galipeau J: Allogeneic marrow stromal cells are immune rejected by MHC class I- and class IImismatched recipient mice. Blood 2005, 106(13):4057-4065.

147. Bensidhoum M, Chapel A, Francois S, Demarquay C, Mazurier C, Fouillard L, Bouchet S, Bertho JM, Gourmelon P, Aigueperse J, et al: Homing of in vitro expanded Stro- $1^{-}$or Stro- $1^{+}$human mesenchymal stem cells into the NOD/SCID mouse and their role in supporting human CD34 cell engraftment. Blood 2004, 103(9):3313-3319.

148. Ball LM, Bernardo ME, Roelofs H, Lankester A, Cometa A, Egeler RM Locatelli F, Fibbe WE: Cotransplantation of ex vivo expanded mesenchymal stem cells accelerates lymphocyte recovery and may reduce the risk of graft failure in haploidentical hematopoietic stem-cell transplantation. Blood 2007, 110(7):2764-2767.

149. Behre G, Theurich S, Weber T, Christopeit M: Reply to 'The correlation between cotransplantation of mesenchymal stem cells and higher recurrence rates in hematologic malignancy patients: outcome of a pilot clinical study'. In Leukemia Edited by: Ning, et al 2009, 23(1):178, author reply $179-180$

150. Le Blanc K, Samuelsson H, Gustafsson B, Remberger M, Sundberg B, Arvidson J, Ljungman P, Lonnies H, Nava S, Ringden O: Transplantation of mesenchymal stem cells to enhance engraftment of hematopoietic stem cells. Leukemia 2007, 21(8):1733-1738.

151. in 't Anker PS, Noort WA, Kruisselbrink AB, Scherjon SA, Beekhuizen W, Willemze R, Kanhai HH, Fibbe WE: Nonexpanded primary lung and bone marrow-derived mesenchymal cells promote the engraftment of umbilical cord blood-derived CD $34^{+}$cells in NOD/SCID mice. Exp Hematol 2003, 31(10):881-889. 
152. Ringden O, Remberger M, Svahn BM, Barkholt L, Mattsson J, Aschan J, Le Blanc K, Gustafsson B, Hassan Z, Omazic B, et al: Allogeneic hematopoietic stem cell transplantation for inherited disorders: experience in a single center. Transplantation 2006, 81(5):718-725.

153. Kong XY, Cai Z, Pan L, Zhang L, Shu J, Dong YL, Yang N, Li Q, Huang XJ, Zuo PP: Transplantation of human amniotic cells exerts neuroprotection in MPTP-induced Parkinson disease mice. Brain Res 2008, 1205:108-115.

154. Zhao P, Ise H, Hongo M, Ota M, Konishi I, Nikaido T: Human amniotic mesenchymal cells have some characteristics of cardiomyocytes. Transplantation 2005, 79(5):528-535.

155. Kubo M, Sonoda Y, Muramatsu R, Usui M: Immunogenicity of human amniotic membrane in experimental xenotransplantation. Invest Ophthalmol Vis Sci 2001, 42(7):1539-1546.

156. Walther G, Gekas J, Bertrand OF: Amniotic stem cells for cellular cardiomyoplasty: promises and premises. Catheter Cardiovasc Interv 2009, 73(7):917-924

157. Prather WR, Toren A, Meiron M: Placental-derived and expanded mesenchymal stromal cells (PLX-I) to enhance the engraftment of hematopoietic stem cells derived from umbilical cord blood. Expert Opin Biol Ther 2008, 8(8):1241-1250.

158. Hiwase SD, Dyson PG, To LB, Lewis ID: Cotransplantation of placental mesenchymal stromal cells enhances single and double cord blood engraftment in nonobese diabetic/severe combined immune deficient mice. Stem Cells 2009, 27(9):2293-2300.

doi:10.1186/1423-0127-18-49

Cite this article as: Chen et al: Immunomodulatory properties of human adult and fetal multipotent mesenchymal stem cells. Journal of

Biomedical Science 2011 18:49.

\section{Submit your next manuscript to BioMed Central and take full advantage of:}

- Convenient online submission

- Thorough peer review

- No space constraints or color figure charges

- Immediate publication on acceptance

- Inclusion in PubMed, CAS, Scopus and Google Scholar

- Research which is freely available for redistribution

Submit your manuscript at www.biomedcentral.com/submit 